\title{
Identifikasi Taenia solium secara Mikroskopis pada Peternakan Babi
}

\section{Microscopic Identification of Taenia solium in Pig Farms}

\author{
Heri Setiyo Bekti ${ }^{1}$, Nur Habibah ${ }^{2}$, Luh Putu Rinawati ${ }^{3}$, Ni Putu Candra Dewi Pradnya Yasa ${ }^{4}$ \\ Oktavelendi Dhaneta Graha Rindi ${ }^{5}$, Ni Km Ayu Kusuma Dewi', Ni Putu Ayu Dani Savitri ${ }^{7}$, \\ Aprilia Rakhmawati ${ }^{8}$ \\ Prodi Teknologi Laboratorium Medis, Politeknik Kesehatan Denpasar, Indonesia
}

\begin{tabular}{l} 
ARTICLE INFO \\
\hline Article history \\
Received date \\
01 Mar 2021 \\
Revised date \\
07 Mar 2021 \\
Accepted date \\
08 Apr 2021 \\
\hline
\end{tabular}

Keywords:

Cysticercosis;

Pig;

Taenia solium.

Kata kunci:

Cysticercosis;

Babi;

Taenia solium.

\begin{abstract}
ABSTRAK
Taenia solium is a zoonosis found all over the world, especially in developing countries. $T$ solium can cause taeniasis and cysticercosis in humans. Pigs as intermediate hosts can be infected with $T$ solium which causes porcine cysticercosis. $T$ solium can infect muscle, skin, eye, and brain tissue which can develop into neurocysticercosis. Neurocysticercosis is the cause of $30 \%$ of cases of epilepsy in the world. In Denpasar city, pigs are one type of livestock. A large number of pig farms and the Balinese's people's habit of consuming pork is one of the sources of $T$ solium infection. This research was conducted to determine $T$ solium eggs in pig feces. The study was conducted microscopically on 31 samples with simple random sampling technique. The results showed that of the 31 samples examined, $54.8 \%$ (17 samples) were positive for $T$ solium eggs. This indicates that the pig farms in Denpasar city have been infected with $T$ solium. Pig farming in Denpasar city was done traditionally and kept indoors. However, the breeders pay less attention to pig health and environmental sanitation. Also, pigs are slaughtered privately by breeders because there are no slaughterhouses. Lack of supervision of pork circulating in the community is also the cause of $T$ solium infection. Therefore, it is necessary to carry out supervision by the local government on pig farms as well as supervision of pork consumed by the public to prevent and eradicate $T$ solium infection.
\end{abstract}

Taenia solium merupakan zoonosis yang ditemukan di seluruh dunia, terutama di negaranegara berkembang. $T$ solium dapat menyebabkan taeniasis dan sistiserkosis pada manusia. Babi sebagai hospes perantara yang dapat terinfeksi $T$ solium yang menyebabkan sistiserkosis babi. T solium dapat menginfeksi jaringan otot, kulit, mata, serta otak yang dapat berkembang menjadi neurocysticercosis. Neurocysticercosis merupakan penyebab 30\% kasus epilepsi di dunia. Di kota Denpasar, babi merupakan salah satu jenis hewan ternak. Banyaknya peternakan babi dan kebiasaan masyarakat Bali mengonsumsi daging babi merupakan salah satu sumber infeksi $T$ solium. Penelitian ini dilakukan untuk mengetahui telur $T$ solium pada feses babi. Penelitian dilakukan secara mikroskopik terhadap 31 sampel dengan teknik simple random sampling. Hasil penelitian menunjukkan bahwa dari 31 sampel yang diperiksa sebanyak 54,8\% (17 sampel) positif mengandung telur $T$ solium. Hal ini menunjukkan bahwa peternakan babi di kota Denpasar telah terinfeksi $T$ solium. Peternakan babi di kota Denpasar dilakukan secara tradisional dan dipelihara di dalam ruangan. Namun, para peternak kurang memperhatikan kesehatan babi dan sanitasi lingkungan. Selain itu, babi disembelih secara pribadi oleh peternak karena tidak ada tempat penyembelihan hewan. Kurangnya pengawasan terhadap daging babi yang beredar di masyarakat juga menjadi penyebab infeksi $T$ solium. Oleh karena itu, perlu dilakukan pengawasan oleh pemerintah setempat terhadap peternakan babi serta pengawasan terhadap daging babi yang dikonsumsi masyarakat untuk mencegah dan memberantas infeksi T solium.

Corresponding Author:

Heri Setiyo Bekti

Prodi Teknologi Laboratorium Medis, Politeknik Kesehatan Denpasar, Indonesia

Email: herisetiyob7@gmail.com 


\section{PENDAHULUAN}

Cacing merupakan parasit manusia yang ada sejak waktu yang lama (Hotez, et al., 2008) dan sampai sekarang masih menjadi masalah kesehatan utama di dunia, dengan jumlah penderita lebih dari 1,5 juta jiwa. Penyebab kematian tertinggi disebabkan oleh Taenia spp. (WHO, 2016).

Di Asia terdapat tiga spesies Taenia yaitu Taenia saginata, Taenia solium, dan Taenia asiatica. Dari ketiga spesies tersebut, $T$ solium mempunyai peran yang paling besar terhadap masalah kesehatan. Taenia saginata dan Taenia solium termasuk ke dalam kelas cestoda dari filum Plathyhelminthes. Cacing pada kelas cestoda mempunyai bentuk pipih dan tubuhnya terdiri dari segmen-segmen yang disebut proglotid. Pada tiap proglotid mempunyai susunan alat kelamin jantan dan betina, yang disebut sebagai hemaprodit. Infeksi yang disebabkan oleh $T$ solium dapat terjadi dalam dua kondisi, yaitu taeniasis yang merupakan infeksi yang disebabkan cacing dewasa dan sistiserkosis yang merupakan infeksi yang disebabkan akibat larva cacing. Hospes perantara $T$ solium adalah babi. Identifikasi infeksi lebih mudah ditegakkan dengan konfirmasi telur atau larva pada babi karena identifikasi dari lingkungan sangat sulit dilakukan (Garcia, et al., 2014; Flisser, 2013; Ito, et al., 2003).

Infeksi pada manusia terjadi melalui larva cacing yang terdapat pada daging babi dan telur cacing yang dikleluarkan oleh karier, pada umumnya manusia (Wandra et al., 2013). Infeksi larva cacing yang berkembang pada jaringan otot, kulit, mata, serta otak dapat berkembang menjadi neurocysticercosis. Neurocysticercosis merupakan penyebab 30\% kasus epilepsi di dunia (Garcia et al., 2014; Walker \& Zunt, 2005; WHO, 2016). Penderita infeksi ini umumnya asimptomatik dalam jangka waktu 10 tahun dan menjadi karier (Garcia, et al., 2014; Ito, et al., 2003).

Peningkatan prevalensi taeniasis salah satunya disebabkan karena adanya peningkatan produksi daging babi yang menyebabkan terjadinya peningkatan peternakan babi, terutama peternakan babi dengan biaya rendah dengan sanitasi yang buruk (Montresor \& Palmer, 2006). Selain itu, konsumsi daging babi yang mentah dan tidak dimasak dengan benar juga meningkatkan prevalensi infeksi (Wandra, et al., 2011).

Berdasarkan data WHO tahun 2016, Indonesia merupakan salah satu negara endemik $T$ solium (WHO, 2016). Di Indonesia, beberapa data menunjukkan bahwa taeniasis paling banyak ditemukan di tiga propinsi yaitu Papua, Bali, dan Sumatera Utara. Selain itu, penyakit ini juga ditemukan di Lampung, Sulawesi Utara, Sulawesi Tenggara, Nusa Tenggara Timur, dan Kalimantan Barat (Wandra, et al., 2011, 2013). Di Bali, kasus taeniasis/sistiserkosis pertama kali dilaporkan pada tahun 1928 pada hewan ternak dan babi dan mencapai kasus tertinggi pada tahun 1975 sampai dengan 1990, dengan data kasus taeniasis 50 pasien/tahun. Pada tahun 2017, kasus taeniasis di Bali dapat diturunkan dan hanya ditemukan kasus sporadik di beberapa tempat. Tahun 2018, Winianti dkk mendeteksi 2 kasus taeniasis dari 98 orang yang diteliti di Karangasem (Winianti, et al., 2018). Daerah dengan resiko tinggi diperlukan upaya pencegahan yang menyeluruh dan program pengawasan yang sesuai untuk mencegah potensi transmisi taeniasis (Wandra, et al., 2011). Selain itu, masyarakat Bali juga mempunyai kebiasaan memakan lawar babi. Lawar merupakan makanan tradisional penduduk Bali yang terbuat dari daging babi mentah.

Diagnosa laboratorium untuk identifikasi taeniasis pada umumnya dilakukan dengan menggunakan metode morfologi, yaitu dengan cara menemukan telur dan proglatid pada sampel feses penderita. Pada metode morfologi, dapat digunakan pewarna untuk mengamati morfologi telur atau proglatid, yaitu pewarna Ziehl-Neelsen dan Hematoxylin-Eosin (Parija \& Ponnambath, 2013). Penelitian yang dilakukan oleh Wandra, dkk (2011), menyebutkan bahwa masih terdapat potensi endemik taeniasis di Bali. Tahun 2011 ditemukan 80 kasus taeniasis karena $T$ saginata, 2 kasus karena infeksi $T$ saginata dan $T$ solium, serta 12 kasus neurocysticercosis yang terjadi pada manusia. Penelitian yang dilakukan oleh Dharmawan, dkk (2012) melaporkan bahwa terdapat 50 sampel dari 641 babi yang terdapat di Kabupaten Karangasem menunjukkan hasil seropositif. Beberapa penelitian tersebut dilakukan di luar kota Denpasar. Padahal seperti kita ketahui, Denpasar merupakan pusat kota di Bali dan terdapat beberapa peternakan babi. Untuk mencegah terjadinya transmisi dan mengetahui terjadinay infeksi cacing $T$ solium, terutama di wilayah kota Denpasar diperlukan informasi yang berbasis data hasil riset. Hal ini juga akan meningkatkan keamanan dan kenyamanan, terutama di bidang kesehatan pariwisata mengingat kota Denpasar juga memiliki kunjungan wisatawan yang cukup tinggi setiap tahunnya. 


\section{METODE}

Penelitian ini merupakan penelitian deskriptif dengan desain observasional. Penelitian ini digunakan untuk menggambarkan taeniasis pada peternakan babi yang terdapat di Kota Denpasar.

Sampel dalam penelitian ini berupa feses babi. Pengumpulan sampel dilakukan dari peternakan babi yang terdapat di Kabupaten Denpasar. Teknik sampling yang digunakan merupakan teknik simple random sampling. Total sampel dalam penelitian ini adalah 31 sampel yang diambil secara proporsional dari 7 peternakan babi yang ada di kota Denpasar.

Instrumen yang digunakan adalah lembar informed concent, lembar wawancara, alat tulis, serta kamera digital. Pengisian informed concent dilakukan dengan wawancara terhadap pemilik peternakan babi, untuk mendapatkan data identitas pemilik peternakan serta kesedian terlibat pada penelitian ini, hanya responden yang menyetujui informed concent yang kami sertakan dalam penelitian ini.

Pengambilan sampel dilakukan menggunakan lidi steril dan dimasukkan ke dalam wadah sampel. Sampel feses ditambahkan $2,5 \%$ potassium dikromat dengan perbandingan 1:2 dan disimpan pada suhu kamar. Sampel diperiksa secara mikroskopik dan hasilnya dimasukkan ke dalam kategori positif atau negatif.

Sampel yang masuk ke dalam kategori positif merupakan sampel yang telah diperiksa secara mikroskopik dan ditemukan adanya telur $T$ solium.

Pemeriksaan sampel dilakukan di laboratorium molekuler Jurusan Analis Kesehatan Poltekkes Kemenkes Denpasar. Sampel yang akan diperiksa ditambah larutan $\mathrm{NaCl}$ jenuh kemudian dihomogenkan. Kemudian ditutup dengan cover glass dan didiamkan pada suhu $27^{\circ} \mathrm{C}$ selama 15 menit. Larutan paling atas diambil dan diteteskan pada obyek glass dengan ditambah larutan lugol 1\%. Selanjutnya ditutup dengan cover glass. Sampel diamati menggunakan mikroskop dengan perbesaran obyektif 40x.

Data yang diperoleh dianalisis menggunakan rumus :

$x=\mathrm{F} / \mathrm{n} \times \mathrm{K}$

Keterangan:

$X$ : persentase

$\mathrm{F}$ : Frekuensi kategori variabel yang diamati

$\mathrm{N}$ : jumlah sampel penelitian

K : Konstanta (100\%) (Nasir et al., 2011)
Penelitian ini telah mendapatkan persetujuan etik (ethical approval) Nomor: LB.02.03/EA/KEPK/0324/2019 oleh Komisi Etik Penelitian Kesehatan Politeknik Kesehatan Denpasar.

\section{HASIL}

Berdasarkan survei lapangan yang telah kami lakukan, di kota Denpasar terdapat 7 peternakan babi. Dari 7 peternakan babi yang ada, semua pemilik peternakan bersedia untuk menjadi responden dalam penelitian ini dengan menyetujui informed concent yang telah disediakan.

Dari hasil wawancara didapatkan rata-rata peternakan babi, memiliki 7 kandang babi, dengan jumlah babi \pm 30 babi pada tiap peternakan, baik babi yang sudah deewasa maupun yang belum dewasa. Peternakan umumnya mempunyai jarak yang dekat dengan pemukiman warga. Kondisi kandang dibuat dengan tidak sepenuhnya tertutup, sehingga sirkulasi udara dan pencahayaan cukup baik, serta pembersihan kandang dilakukan tiap hari, dengan melakukan penyemprotan air

Pemeriksaan secara mikroskopik dilakukan untuk mengetahui ada tidaknya telur $T$ solium yang ada di feses babi. Sampel yang diperiksa dikategorikan ke dalam kategori positif dan negatif. Kategori positif ditunjukkan dengan ditemukannya telur $T$ solium pada sampel. Sedangkan kategori negatif ditunjukkan dengan tidak ditemukannya telur $T$ solium.

Hasil pemeriksaan mikroskopik $T$ solium pada feses babi yang dilakukan terhadap 31 sampel, ditemukan 54,8\% (17 sampel) positif yang mengandung telur $T$ solium seperti ditunjukkan pada tabel 1 .

\section{Tabel 1. Jumlah Pengamatan Mikroskopis Feses Babi

Hasil Pengamatan Jumlah

\begin{tabular}{lc}
\hline (+) Taenia & 17 \\
(-) Taenia & 14 \\
Total & 31 \\
\hline
\end{tabular}

Hasil positif ditunjukkan dengan ditemukannya telur $T$ solium pada sampel yang diperiksa. Hasil tersebut menggambarkan bahwa babi yang dipelihara di peternakan babi yang ada di kota Denpasar telah terinfeksi $T$ solium seperti yang terlihat pada Gambar 1. 


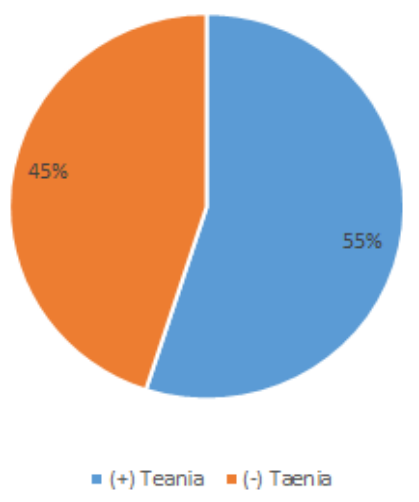

Gambar 1. Grafik Persentase (\%) Pengamatan Mikroskopis Sampel Feses Babi

Pengamatan sampel feses babi yang diperoleh dari peternakan babi di kota Denpasar dilakukan secara mikroskopik. Hasil pemeriksaan sampel positif yang berarti mengandung telur $T$ solium dapat dilihat seperti pada Gambar 2.

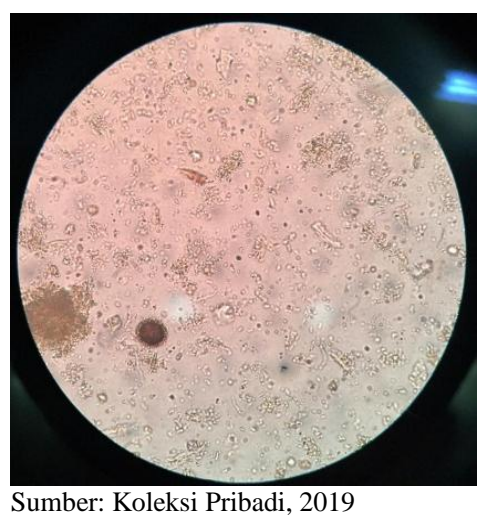

Gambar 2. Hasil Pengamatan Mikroskopis Sampel Feses Babi

\section{PEMBAHASAN}

$T$ solium merupakan agen penyebab sistiserkosis babi serta taeniasis dan sistiserkosis manusia. Infeksi $T$ solium dianggap sebagai parasit zoonosis dengan konsekuensi kesehatan dan dampak ekonomi yang signifikan bagi masyarakat (Murrell, et al., 2005). Babi merupakan hospes perantara bagi $T$ solium. Babi dapat terinfeksi $T$ solium setelah menelan telur cacing yang ada di feses manusia yang terinfeksi (Dharmawan, et al., 2012; Flisser, 2013).

Infeksi $T$ solium pada babi dapat menurunkan nilai jual daging babi sehingga berdampak pada perekonomian masyarakat terutama produsen daging. Hal ini dikarenakan daging atau jeroan babi yang terinfeksi dilarang dikonsumsi dan harus dimusnahkan (Prasad, et al., 2008). Selain itu, babi yang terinfeksi $T$ solium juga berbahaya karena dapat menular ke manusia (Rahayu, 2015).

Di Indonesia, infeksi $T$ solium masih terabaikan. Penyakit ini tersebar di beberapa wilayah dengan jumlah prevalensi yang bervariasi. Hal ini berhubungan erat dengan kebiasaan konsumsi daging babi serta sistem peternakan babi. Peternakan babi tradisional dengan biaya rendah dan sanitasi yang buruk menjadi salah satu penyebab terjadinya infeksi $T$ solium. Babi dapat terinfeksi $T$ solium karena memakan makanan yang terkontaminasi feses penderita (Dharmawan, et al., 2012; Flisser, 2013).

Terdapat 3 propinsi endemik taeniasis/sistiserkosis di Indonesia, yaitu: Papua, Bali, dan Sumatra Utara. Sedangkan di Lampung, Jakarta, Jawa Timur, Sulawesi Selatan, Sulawesi Utara, dan Nusa Tenggara Timur, kasus taeniasis dan sistiserkosis tersebar secara sporadik (Wandra, et al., 2011, 2013).

Bali merupakan salah satu propinsi endemik untuk taeniasis yang disebabkan $T$ saginata dan taeniasis/sistiserkosis yang disebabkan $T$ solium (Sudewi, et al., 2008; Wandra et al., 2006). Tahun 2011, Wandra et al, mendeteksi 80 kasus taeniasis karena $T$ saginata, 2 kasus karena infeksi $T$ saginata dan $T$ solium, serta 12 kasus neurocysticercosis yang terjadi pada manusia (Wandra, et al., 2011).

Manusia dapat terinfeksi $T$ solium jika memakan daging mentah atau daging diolah dengan tidak sempurna yang mengandung kista larva. Setelah tertelan, kista larva masuk ke usus manusia, di usus manusia kista larva berkembang menjadi cacing dewasa. Infeksi pada manusia dapat berupa taeniasis atau sistiserkosis (Mayta, et al., 2008).

Hingga saat ini laporan mengenai distribusi sistiserkosis pada babi dan hewan ternak di dunia, termasuk Indonesia sangat jarang ditemukan. Umumnya data sistiserkosis pada hewan hanya berdasarkan data dari inspeksi daging yang dilakukan oleh pemerintah daerah setempat. Sehingga data yang diperoleh umumnya kurang dari keadaan sebenarnya dan tidak lengkap. Hal ini yang menyebabkan kasus sistiserkosis pada hewan sangat jarang ditemui bahkan seperti tidak ada kasus (Wandra, et al., 2011).

Laporan mengenai sistiserkosis pada hewan dapat tersedia jika dilakukan program surveilans atau penelitian yang spesifik mengenai sistiserkosis pada hewan. Dalam hal ini dukungan dari pemerintah setempat dan para peneliti sangat dibutuhkan. Dengan adanya laporan mengenai distribusi sistiserkosis pada 
hewan dapat digunakan untuk menentukan strategi untuk mengontrol, mencegah, dan memberantas sistiserkosis pada hewan sehingga tidak sampai menular ke manusia (Wandra, et al., 2011).

Babi merupakan salah satu komunitas ternak penghasil daging yang mempunyai potensi dan prospek yang baik. Hal ini dikarenakan laju pertumbuhan yang cepat, tingginya jumlah anak perkelahiran serta memiliki tingkat adaptasi yang tinggi terhadap makanan dan lingkungan menjadikan babi sebagai hewan ternak yang memiliki potensi besar. Selain itu, pasar komoditas babi masih terbuka lebar ke berbagai negara (Kementerian Pertanian, 2016; Podung \& Asiani, 2018).

Di Bali, ternak babi merupakan salah satu sumber pendapatan bagi masyarakatnya. Sekitar $80 \%$ penduduk Bali di area pedesaan memelihara babi. Hal ini berkaitan dengan mayoritas penduduk yang non Muslim serta budaya yang ada. Kebiasaan masyarakat Bali mengonsumsi daging babi menjadi salah satu faktor banyaknya peternakan babi di Bali. Selain itu, babi juga digunakan untuk keperluan upacara adat dan agama (Budaarsa, 2014).

Denpasar selain sebagai ibukota provinsi Bali, juga merupakan pusat kegiatan bisnis dan merupakan salah satu tujuan wisata popular bagi wisatawan nusantara dan mancanegara. Tidak hanya karena ada banyak objek wisata, Kota Denpasar juga memiliki beragam kuliner khas Bali yang menjadi daya tarik bagi para wisatawan, salah satunya babi guling. Babi guling merupakan salah satu makanan khas Bali yang populer selain ayam betutu (Dinas Pariwisata, 2016; Utama, 2017).

Peternakan babi yang terdapat dikota Denpasar memiliki rerata \pm 71 babi/peternak, yang umumnya dikelola dengan sistem tradisonal, yaitu lokasi yang dekat dengan pemukiman/tempat tinggal dan akses yang cukup bebas, yang bertujuan memudahkan dalam hal perawatan sehari-hari. Peternakan babi yang dekat dengan pemukiman dapat menyebabkan resiko terjadinya taeniasis, faktor resiko taeniasis pada manusia dan babi adalah dengan keberadaaan cacing $T$ solium diantara pemukiman penduduk (Ito, et al., 2003), hal ini karena kemampuan bebarapa serangga yang dapat menyimpan telur cacing telur $T$ solium dan menyimpan telur pada saluran pencernaanya selama beberapa minggu.

Peternakan belum melakukan pengelolan pembuangan limbah kotoran peternakan dengan baik, dimana pengelolalan limbah kotoran masih berdekatan dengan saluran limbah dari pemukiman yang terdapat disekitar peternakan. Kotoran ternak babi dapat dimanfaatkan sebagai pupuk organik. Kotoran ternak yang tidak diolah dapat mengganggu kebersihan lingkungan, sanitasi kandang, serta dapat menimbulkan bau tidak sedap di sekitar kandang (Sapanca, et al., 2015). Oleh karena itu perlu diadakan penyuluhan tentang pengolahan limbah ternak menjaddi pupuk organik yang dapat dijual sehingga bisa menjadi pemasukan tambahan bagi peternak.

Dengan ditemukannya hasil positif telur $T$ solium pada feses babi di peternakan babi di kota Denpasar, upaya pengendalian dan pemberantasan infeksi $T$ solium pada babi perlu dilakukan.

Para peternak babi dapat memberikan obat cysticidal sebagai pengobatan anti cacing. Beberapa obat anti parasit yang telah diuji misalnya albendazole sulphoxide, albendazole, praziquantel, oxfendazole, dan flubendazole. Pemberian oxfendazole paling disukai. Oxfendazole merupakan golongan obat benzimidazole, obat ini tidak mahal, mudah diberikan dan manjur melawan cacing baik berupa larva maupun cacing dewasa. Dosis tunggal $30 \mathrm{mg} / \mathrm{kg}$ dapat membunuh semua kista di otot babi (Gabriël, et al., 2016; Gonzalez, et al., 2001, 2003). Selain dengan pemberian obat, sistiserkosis pada babi juga bisa diobati dengan tindakan pembedahan (operasi) (Estunigsih, 2009).

Pencegahan infeksi $T$ solium pada babi dapat dilakukan dengan penerapan peternakan babi yang higienis dengan memperhatikan sanitasi lingkungan (Gilman, et al., 2012). Peternakan babi di kota Denpasar dilakukan secara tradisional. Meskipun babi dikurung dalam kandang dan tidak dilepas secara liar, para peternak babi masih kurang memperhatikan sanitasi kandang terutama penyemprotan desinfektan.

Para peternak perlu memperhatikan beberapa hal terkait sanitasi seperti, air, udara, pakan, lingkungan, peralatan, termasuk pekerja kandang. Meskipun sanitasi di peternakan kota Denpasar sudah tergolong baik, masih perlu dilakukan penyemprotan desinfektan pada kandang ternak secara teratur. Dengan begitu, kandang dan lingkungan di sekitarnya tetap bersih sehingga mampu mencegah berkembangnya penyakit pada babi. Kandang babi yang dibuat juga harus memenuhi persyaratan.

Selain sanitasi, para peternak juga perlu memperhatikan pakan yang diberikan. Babi membutuhkan air, protein, mineral, energi, dan 
vitamin agar pertumbuhannya optimal. Pakan yang diberikan dapat memberikan efek bagi pertumbuhan dan kesehatan babi. Patokan utama dalam pemberian pakan babi adalah kebutuhan protein dan energinya.

Pemberian obat cacing dan vaksin terhadap babi juga harus dilakukan sesuai jadwal. Misalnya pemberian vaksin hog cholera/clasiccal swine fever. Vaksinasi dilakukan agar babi memiliki antibodi terhadap agen penyakit yang dapat menyerang babi seperti Hog Cholera, Pasteurella/SE, dan lain-lain. Vaksinasi sangat penting dan harus dilakukan karena waktu hidup babi yang cukup lama yaitu sekitar 5 tahun. Pemberian obat cacing/antelmintika digunakan untuk mengurangi atau membasmi cacing yang ada dalam rumen usus atau jaringan tubuh babi. Selain obat cacing, babi juga perlu diberikan suplemen, vitamin, serta anti bakteri agar kesehatan babi terjaga dan mikroorganisme penyebab penyakit yang ada di dalam tubuh babi terbunuh (Kementerian Pertanian, 2016; Sapanca, et al., 2015).

Di kota Denpasar, para peternak juga menyembelih babi secara pribadi dikarenakan tidak adanya tempat pemotongan hewan di sekitar peternakan. Babi yang dipotong juga tanpa melalui pemeriksaan kesehatan ternak. Selain menyembelih sendiri, para peternak juga menjual sendiri daging yang sudah disembelih tanpa melalui inspeksi daging yang seharusnya dilakukan oleh pemerintah setempat.

Oleh karena itu, penyuluhan mengenai kebersihan dan kesehatan hewan ternak perlu dilakukan kepada para peternak babi di kota Denpasar. Agar para peternak memahami pentingnya sanitasi kandang dan kesehatan ternaknya (Bulu, et al., 2019). Selain itu juga perlu dilakukan pemeriksaan feses babi secara rutin untuk mengetahui ada tidaknya telur cacing pada babi. Dengan mengetahui infeksi cacing maka pengobatan dapat segera dilakukan (Andriaty, 2015; Kementerian Pertanian, 2016).

Telur cacing dapat ditemukan di feses dengan pemeriksaan secara mikroskopik. Pengamatan secara mikroskopis merupakan alat diagnostik standar, yang masih banyak digunakan sebagai pemeriksaan rutin di banyak laboratorium (Gilman, et al., 2012). Metode ini menggunakan alat dan bahan yang mudah digunakan. Selain itu, langkah pemeriksaannya cukup sederhana. Sehingga sampai saat ini pemeriksaan telur cacing secara mikroskopik masih menjadi pemeriksaan yang paling banyak digunakan di laboratorium untuk diagnosis taeniasis dan sistiserkosis (Morales-Gomez, et al., 2017; Nezar, 2014), meskipun pemeriksaan ini memiliki sensitivitas yang tinggi akan tetapi spesifitasnya rendah, yang disebabkan morfologi telur pada spesies Taenia spp yang mirip, serta pengamatan struktur internal proglotid untuk menentukan spesies Taenia sp. (Gilman, et al., 2012)

Telur $T$ solium dapat bertahan selama delapan minggu di lingkungan luar hospes, serta infektif baik bagi manusia serta babi (Eom, 2011). T solium pada babi dapat ditemukan pada daging lidah, jantung, otak, bahu, dan leher (Estunigsih, 2009).

Diagnosis taeniasis dapat dilakukan dengan mengidentifikasi telur dan proglotid cacing pada feses secara mikroskopik. Telur cacing Taenia berbentuk spherical, mengandung embrio, dan berwarna coklat. Pada larutan garam jenuh, telur akan mengapung. Dengan cara membedakan morfologinya, proglotid Taenia dapat dibedakan dari cacing pita lainnya (Eom, et al., 2011; Estunigsih, 2009).

Babi rentan terhadap beberapa penyakit salah satunya sistiserkosis. Daging babi yang terinfeksi sistiserkosis dilarang untuk diperjualbelikan dan harus dimusnahkan sehingga akan mengakibatkan kerugian bagi para peternak. Pemahaman mengenai kebersihan dan kesehatan ternak dapat membuat produksi daging babi meningkat. Selain itu, para peternak juga akan memahami penanganan ternak yang bermasalah sebelum terlambat (Bulu, et al., 2019).

Upaya pengendalian dan pemberantasan infeksi $T$ solium pada babi juga dapat dilakukan melalui adanya pengawasan terhadap daging yang dijual, pengolahan daging babi yang benar serta tidak mengonsumsi daging babi mentah (Gilman, et al., 2012). Kebiasaan masyarakat Bali mengonsumsi daging babi mentah dapat menjadi faktor resiko terjadinya taeniasis. Inspeksi daging yang dilakukan oleh pemerintah setempat perlu dilakukan untuk mencegah peredaran daging babi yang terinfeksi $T$ solium di masyarakat.

Tidak adanya tempat pemotongan hewan di sekitar peternakan babi di Denpasar, juga menjadi salah satu faktor resiko $T$ solium yang ada di babi menular ke manusia. Sehingga pemerintah daerah bersama masyarakat perlu mengadakan tempat pemotongan hewan yang memenuhi syarat. Hal ini dimaksudkan agar daging babi yang beredar di masyarakat tidak terinfeksi $T$ solium.

Tindakan pencegahan, pengendalian, dan pemberantasan infeksi $T$ solium sangat penting dilakukan. Manusia bisa terinfeksi $T$ solium jika mengonsumsi daging atau jeroan babi yang mentah atau dimasak dengan tidak benar 
(Dharmawan, et al., 2012; Flisser, 2013). Penyuluhan tentang cara memasak daging babi dengan benar perlu disosialisasikan kepada seluruh masyarakat. Memasak daging babi dapat dilakukan pada suhu di atas $50^{\circ} \mathrm{C}$ selama 30 menit agar kista larva cacing yang ada di daging mati (Soedarto, 2012).

Infeksi cacing dewasa $T$ solium pada manusia bisa menyebabkan taeniasis dan larva cacing ini dapat menyebabkan sistiserkosis. Larva cacing dapat berkembang pada jaringan otot, kulit, mata, serta otak dapat berkembang menjadi neurocysticercosis (NCC). Neurocysticercosis merupakan penyebab 30\% kasus epilepsi di dunia (Walker and Zunt, 2005; WHO, 2016). Kebanyakan pasien dengan NCC terkait epilepsi mengalami kejang. Kejang merupakan manifestasi yang sangat sering pada pasien dengan kista $T$ solium (Garcia, et al., 2014).

\section{DAFTAR PUSTAKA}

Andriaty, V. (2015). Kejadian nematodiasis gastrointestinal pada pedet sapi bali di kec. marioriwawo, kab. soppeng. [Skripsi]. Makassar: Universitas Hasanuddin.

Budaarsa, K. (2014). Potensi Ternak Babi dalam Menyumbangkan Daging di Bali. Seminar Nasional Ternak Babi, 1-18.

Bulu, P. M., Wera, E., \& Yuliani, N. S. (2019). Manajemen Kesehatan pada Ternak Babi di Kelompok Tani Sehati Kelurahan Tuatuka, Kecamatan Kupang Timur, Kabupaten Kupang, NTT. Jurnal Pengabdian Masyarakat Peternakan, 4(2), 164-176.

Dharmawan, N. S., Swastika, I. K., Putra, I. M., Wandra, T., Sutisna, P., Okamoto, M., \& Ito, A. (2012). Present Situation and Problems of Cysticercosis in Animal in Bali and Papua. Jurnal Veteriner, 13(2), 154-162.

Dinas Pariwisata. (2016). Profil Dinas pariwisata kota Denpasar 2016. Dinas Pariwisata Kota Denpasar.

Eom, K. S., Chai, J. Y., Yong, T. S., Min, D. Y., Rim, H. J., Kihamia, C., \& Jeon, H. K. (2011). Morphologic and genetic identification of Taenia Tapeworms in Tanzania and DNA genotyping of Taenia solium. Korean Journal of Parasitology, 49(4),

399-403.

\section{SIMPULAN}

Simpulan dari penelitian ini yaitu diperoleh 17 sampel $(54,8 \%)$ sampel positif telur $T$ solium dari 31 sampel feses babi di 7 peternakan babi yang ada di kota Denpasar. Infeksi $T$ solium pada babi dapat disebabkan karena sistem peternakan babi yang kurang memperhatikan kesehatan babi dan sanitasi lingkungan. Beberapa faktor resiko yang dapat menyebabkan infeksi $T$ solium pada babi antara lain kebiasaan masyarakat mengonsumsi daging babi mentah atau daging babi yang dimasak dengan tidak sempurna, limbah ternak yang belum ditangani dengan baik, pemotongan babi tanpa melalui pemeriksaan kesehatan ternak.

Penulis menyarankan agar dilakukan penelitian lebih lanjut mengenai infeksi $T$ solium pada babi di kota Denpasar agar dapat dilakukan upaya pencegahan dan pemberantasan infeksi tersebut. Mengingat kota Denpasar merupakan salah satu kota yang memiliki potensi wisata besar di Indonesia.

https://doi.org/10.3347/kjp.2011.49.4.399

Estunigsih, S. E. (2009). Taeniasis dan sistiserkosis merupakan penyakit zoonosis parasiter. Wartazoa, 19(2), 84-92.

Flisser, A. (2013). State of the art of Taenia solium as compared to Taenia asiatica. Korean Journal of Parasitology, 51(1), 43-49. https://doi.org/10.3347/kjp.2013.51.1.43

Gabriël, S., Dorny, P., Mwape, K. E., Trevisan, C., Braae, U. C., Magnussen, P., \& Thys, S. (2016). Control of Taenia solium taeniasis/cysticercosis: The best way forward for sub-Saharan Africa? Acta Tropica, 165, 252-260.

https://doi.org/10.1016/j.actatropica.2016.04. 010

Garcia, P. H. H., Nash, T. E., \& Oscar, H. D. B. (2014). Clinical symptoms, diagnosis, and treatment of neurocysticerosis. Lancet Neurol, 13(12), 1202-1215. https://doi.org/10.1016/S14744422(14)70094-8.Clinical

Gilman, R. H., Gonzalez, A. E., Llanos-zavalaga, F., Tsang, V. C. W., Garcia, H. H., \& Working, C. (2012). Prevention and control of Taenia solium taeniasis / cysticercosis in Peru. Pathogens and Global Health, 106(5), 312-318. https://doi.org/10.1179/2047773212Y.000 0000045 
Gonzalez, A. E., Garc1, H. H., Gilman, R. H., Tsang, V. C. W., \& Working, C. (2003). Control of Taenia solium. Acta Tropica, 87, 103-109. https://doi.org/10.1016/S0001706X(03)00025-1

Gonzalez, A. E., Gavidia, C., Falcon, N., Bernal, T., Verastegui, M., Garcia, H. H., Gilman, R. H., \& Tsang, V. C. W. (2001). Protection of Pigs with Cysticercosis from Further Infections After Treatment with Oxfendazole. Am. J. Trop. Med., 65(1), 15-18.

Hotez, P. J., Brindley, P. J., Bethony, J. M., King, C. H., Pearce, E. J., \& Jacobson, J. (2008). Helminth infections: the great neg;ected tropical diseases. The Journal of Clinical Investigation, 118(4), 1311-1321. https://doi.org/10.1172/JCI34261

Ito, A., Nakao, M., \& Wandra, T. (2003). Human taeniasis and cysticercosis in Asia. The Lancet, 362, 1918-1920.

Kementerian Pertanian. (2016). Pedoman Pelaksanaan Pengembangan Budidaya Babi Tahun 2016. Kementerian Pertanian.

Mayta, H., Gilman, R. H., Prendergast, E., Castillo, J. P., Tinoco, Y. O., Garcia, H. H., Gonzalez, A. E., \& Sterling, C. R. (2008). Nested PCR for specific diagnosis of Taenia solium taeniasis. Journal of Clinical Microbiology, 46(1), 286-289. https://doi.org/10.1128/JCM.01172-07

Montresor, A., \& Palmer, K. (2006). Taeniasis / cysticercosis trend worldwide and rationale for control. Parasitol Int, 55, 1-4. https://doi.org/10.1016/j.parint.2005.11.04 5.Taeniasis/cysticercosis

Morales-Gomez, M. A., Gárate, T., Blocher, J., Devleesschauwer, B., Smit, G. S. ., Schmidt, V., Perteguer, M. J., Ludovisi, A., Pozio, E., Dorny, P., Gabriel, S., \& Winkler, A. S. (2017). Present status of laboratory diagnosis of human taeniosis / cysticercosis in Europe. Eur $J$ Clin Microbiol Infect DIs, 36, 2029-2040. https://doi.org/10.1007/s10096-017-3029-1

Murrell, K. D., Dorny, P., Flisser, A., Geerts, S., Kyvsgaard, N. C., Mcmanus, D. P., Nash, T. E., \& Pawlowski, Z. S. (2005). WHO/FAO/OIE Guidelines for the surveillance, prevention and control of taeniosis/cysticercosis (K. D. Murrell (ed.)).

Nasir, A., Muhith, A., \& M.E., I. (2011). Buku Ajar Metodologi Penelitian Kesehatan. 1st ed. Nuha Medika.

Nezar, M. R. (2014). Jenis Cacing pada Feses Sapi di TPA Jatibarang dan KTT Sidomulyo Desa Nongkosawit Semarang. [Skripsi]. Semarang: Fakultas Matematika dan Ilmu Pengetahuan Alam, Universitas Negeri Semarang.

Parija, S. C., \& Ponnambath, D. K. (2013). Laboratory diagnosis of Taenia asiatica in humans and animals. Tropical Parasitology, 3(2), 120-124. https://doi.org/10.4103/2229-5070.122127

Podung, A. J., \& Asiani, S. (2018). Upaya Peningkatan Pengetahuan Peternak Babi terhadap Penyakit Hog Cholera di Kelurahan Kalasey. Jurnal LPPM Bidang Sains Dan Teknologi, 5(59), 19-25.

Prasad, K. N., Prasad, A., Verma, A., \& Singh, A. K. (2008). Human cysticercosis and Indian scenario : a review. J. Biosci, 33(4), $571-582$.

Rahayu, S. (2015). Prevalensi nematodiasis saluran pencernaan pada sapi bali. [Skripsi]. Makassar: Fakultas Peternakan, Universitas Hasanuddin.

Sapanca, P. L. Y., Cipta, I. W., \& Suryana, I. M. (2015). Peningkatan Manajemen Kelompok Ternak Babi di Kabupaten Bangli. Agrimerta, 05(09), 18-25.

Soedarto. (2012). Penyakit Zoonosis Manusia Ditularkan oleh Hewan. Sagung Seto.

Sudewi, A. A. R., Wandra, T., Artha, A., Nkouawa, A., \& Ito, A. (2008). Taenia solium cysticercosis in Bali, Indonesia: serology and mtDNA analysis. Transactions of the Royal Society of Tropical Medicine and Hygiene, 102, 96-98. https://doi.org/10.1016/j.trstmh.2007.06.018

Utama, I. G. B. R. (2017). Integrasi daya tarik wisata kota denpasar bali. Jurnal Perkotaan, 9(1), 48-66.

Walker, M., \& Zunt, J. R. (2005). Neuroparasitic Infections: Cesyodes, Trematodes, and Protozoans. Semin Neurol, 25(3), 262-277. https://doi.org/10.1055/s-2005-

917663. Neuroparasitic

Wandra, T., Depary, A. A., Sutisna, P., Margono, S. S., Suroso, T., Okamoto, M., Craig, P. S., \& Ito, A. (2006). Taeniasis and cysticercosis in Bali and North Sumatra, Indonesia. Parasitology Interanational, 55, S155-S160. https://doi.org/10.1016/j.parint.2005.11.024

Wandra, T., Ito, A., Swastika, K., Dharmawan, N. S., Sako, Y., \& Okamoto, M. (2013). Taeniases and cysticercosis in Indonesia: Past and present situations. Parasitology, 140(13), 1608-1616. https://doi.org/10.1017/S0031182013000863

Wandra, T., Sudewi, A. R., Swastika, I. K., Sutisna, P., Dharmawan, N. S., Yulfi, H., Darlan, D. M., Kapti, I. N., Samaan, G., Sato, M. O., Okamoto, M., Sako, Y., \& Ito, 
A. (2011). Taeniasis/cysticercosis in bali, Indonesia. Southeast Asian Journal of Tropical Medicine and Public Health, 42(4), 793-802.

World Health Organization. (2016). Taenia solium taeniasis/cysticercosis diagnostic tools: report of a stakeholder meeting, Geneva, 17-18 December 2015.

Winianti, N. W., M, E. H., Wijayanti, M. A., Sutisna, P., Kapti, I. N., \& Sudiarta, I. W. (2018). Taeniasis in Karangasem, Bali. Warmadewa Medical Journal, 3(1), 1-5. 